\title{
PENGARUH BELANJA LANGSUNG DAN BELANJA TIDAK LANGSUNG TERHADAP REALISASI ANGGARAN DAN KINERJA INSTANSI PADA DINAS PENANAMAN MODAL DAN PELAYANAN TERPADU SATU PINTU KABUPATEN BALANGAN KALIMANTAN SELATAN
}

\author{
${ }^{1}$ Rediyono, ${ }^{2}$ Ana Rahmiaty, ${ }^{3}$ Didik Cahyono \\ Email : rediyono.putro@gmail.com, didikcahyono86@gmail.com \\ ${ }^{1,2}$ Sekolah Tinggi Ilmu Ekonomi Pancasetia Banjarmasin \\ ${ }^{3}$ Fakultas Keguruan Dan Ilmu Pendidikan, Universitas Mulawarman
}

\begin{abstract}
Abstrak
Tujuan penelitian ini untuk mengetahui dan menganalisis pengaruh belanja langsung terhadap realisasi anggaran, untuk mengetahui dan menganalisis pengaruh belanja tidak langsung berpengaruh signifikan terhadap realisasi anggaran, untuk mengetahui dan menganalisis pengaruh belanja langsung terhadap kinerja instansi, untuk mengetahui pengaruh belanja tidak langsung terhadap kinerja instansi dan untuk mengetahui pengaruh realisasi anggaran berpengaruh signifikan terhadap kinerja instansi pada Dinas Penanaman Modal dan Pelayanan Terpadu Satu Pintu Kabupaten Balangan Kalimantan Selatan. Alat analisis penelitian ini adalah kuantitatif dan teknik analisis data diolah dengan analisis regresi linier berganda sedangkan populasi dan sampel pada penelitian ini laporan keuangan dan anggaran belanja pada Dinas Penanaman Modal dan Pelayanan Terpadu Satu Pintu Kabupaten Balangan Kalimantan Selatan pada periode 2016-2020. Hasil penelitian pertama diketahui bahwa belanja langsung berpengaruh signifikan terhadap realisasi anggaran, kedua diketahui bahwa belanja tidak langsung berpengaruh signifikan terhadap realisasi anggaran, ketiga diketahui bahwa belanja langsung berpengaruh signifikan terhadap kinerja instansi, keempat diketahui bahwa belanja tidak langsung berpengaruh signifikan terhadap kinerja instansi dan kelima diketahui bahwa realisasi anggaran berpengaruh signifikan terhadap kinerja instansi pada Dinas Penanaman Modal dan Pelayanan Terpadu Satu Pintu Kabupaten Balangan Kalimantan Selatan.

Kata Kunci : Belanja Langsung, Belanja Tidak Langsung, Realisasi Anggaran Dan Kinerja Instansi
\end{abstract}

\section{PENDAHULUAN}

Manajemen keuangan daerah adalah pengorganisasian dan pengelolahan sumber-sumber daya atau kekayaan pada suatu daerah untuk mencapai tujuan yang dikehendaki daerah tersebut. Alat untuk melaksanakan manajemen keuangan daerah disebut dengan tata usaha daerah. Pengukuran kinerja keuangan untuk kepentingan publik dapat dijadikan evaluasi dan pemulihan

Al Qalam: Jurnal Ilmiah Keagamaan dan Kemasyarakatan Vol. 16, No. 2

Maret - April 2022 
Rediyono, Ana Rahmiaty, Didik Cahyono : Pengaruh Belanja Langsung dan Belanka Tidak Langsung Terhadap Realisasi Anggaran dan Kinerja Instansi Pada Dinas Penanaman Modal dan Pelayanan Terpadu Satu Pintu Kabupaten Balangan Kalimantan Selatan

kinerja dengan pembanding skema kerja dan pelaksanaannya. Selain itu dapat juga dijadikan sebagai tolak ukur untuk peningkatan kinerja khususnya keuangan pemerintah didaerah pada periode berikutnya. Adanya otonomi daerah tersebut mengakibatkan desentraisasi sistem pemerintahan, pembangunan dan pelayanan masyarakat wajib menyampaikan laporan pertanggungjawaban keuangan untuk dinilai apakah instansi pemerintah berhasil menjalankan tugas dengan baik ataukah tidak.

Penerapan anggaran berbasis kinerja diatur dalam Permendagri Nomor 13 Tahun 2006 dan diubah dengan Permendagri Nomor 59 Tahun 2007 tentang pedoman pengelolaan keuangan daerah. penyusunan Rencana Kerja dan Anggaran Satuan Kerja Perangkat Daerah, ini berarti telah terpenuhinya kebutuhan tentang anggaran berbasis kinerja dan akuntabilitas. Dimana anggaran berbasis kinerja menuntut adanya output optimal atau pengeluaran yang dialokasikan sehingga setiap pengeluaran harus berorientasi atau bersifat ekonomi, efisien dan efektif. Anggaran berbasis kinerja merupakan sistem penganggaran yang berorientasi pada output organisasi dan berkaitan sangat erat dengan visi, misi dan rencana strategis organisasi.

Kinerja anggaran pemerintah daerah selalu dikaitkan dengan bagaimana sebuah unit kerja pemerintah daerah dapat mencapai tujuan kerja dengan alokasi anggaran yang tersedia. Kinerja merupakan pencapaian atas apa yang telah direncanakan, baik oleh pribadi maupun organisasi. ${ }^{1}$ Kinerja menurut Peraturan Menteri dalam Negeri Nomor 13 Tahun 2006 adalah keluaran/hasil dari kegiatan/program yang akan atau telah dicapai sehubungandengan penggunaan anggaran dengan kuantitas dan kualitas yang terukur. Pengukuran kinerja sangat penting untuk menilai akuntabilitas organisasidan manajer dalam menghasilkan pelayanan publik yang lebih baik. Akuntabilitas bukan sekedar kemampuan menunjukkan bagaimana uang publik dibelanjakan, akan tetapi meliputi kemampuan menunjukkan bahwa uang publik tersebut telah dibelanjakan secara ekonomis, efisien, dan efektif. Pengukuran kinerja suatu instansi pemerintah lebih ditekankan pada kemampuan instansi pemerintah dalam menyerap anggaran. Dengan kata lain, suatu instansi dinyatakan berhasil jika dapat menyerap $100 \%$ (seratus persen) anggaran pemerintah, meskipun hasil hasil serta dampak yang dicapai dari pelaksanaan program tersebut masih berada jauh di bawah standar (ukuran mutu). ${ }^{2}$

Menurut Widodo anggaran daerah atau Anggaran Pendapatan dan Belanja Daerah (APBD) merupakan instrumen kebijakan yang utama bagi pemerintah daerah. ${ }^{3}$ Anggaran daerah

\footnotetext{
${ }^{1}$ Nugroho dan Rohman, Ekonomi Pembangunan (Jakarta: Liberty, 2012), 1.

${ }^{2}$ Mahsun, Manajemen Keuangan Publik (Jakarta: PT. Rajawali Press, 2006), 122.

${ }^{3}$ Arya Widodo, Penganggaran (Bandung: Buana Press, 2011), 99.
}

Al Qalam: Jurnal Ilmiah Keagamaan dan Kemasyarakatan Vol. 16, No. 2 Maret - April 2022 
Rediyono, Ana Rahmiaty, Didik Cahyono : Pengaruh Belanja Langsung dan Belanka Tidak Langsung Terhadap Realisasi Anggaran dan Kinerja Instansi Pada Dinas Penanaman Modal dan Pelayanan Terpadu Satu Pintu Kabupaten Balangan Kalimantan Selatan

menduduki posisi sentral dalam upaya pengembangan kapabilitas, efisiensi, danefektifitas pemerintah daerah. Anggaran daerah seharusnya dipergunakan sebagai alat untuk menentukan besarnya pendapatan, pengeluaran, dan pembiayaan, alat bantu pengambilan keputusan dan perencanaan pembangunan, alat otoritas pengeluaran di masa yang akan datang, ukuran standar untuk evaluasi kinerja serta alat koordinasi bagi semua aktivitas di berbagai unit kerja. Anggaran daerah merupakan rencana keuangan yang menjadi dasar dalam pelaksanaan pelayanan publik.

Melihat berbagai permasalahan yang diuraikan diatas, peneliti berkeinginan untuk melakukan penelitian mengenai “Pengaruh Belanja Langsung dan Belanja Tidak Langsung Terhadap Realisasi Anggaran dan Kinerja Instansi pada Dinas Penanaman Modal dan Pelayanan Terpadu Satu Pintu Kabupaten Balangan Kalimantan Selatan”.

\section{METODE PENELITIAN}

Penelitian ini berdasarkan jenis data, merupakan penelitian asosiatif dengan paradigma kuantitatif. Penelitian ini bertujuan untuk mengetahui hubungan antara dua variabel atau lebih dengan menggunakan data numerik. Bentuk hubungan variabel pada penelitian ini berupa hubungan kausal (sebab-akibat), yang ditunjukkan dengan pengaruh variabel independen terhadap variabel dependen. Penelitian ini bertujuan untuk memperoleh kejelasan hubungan antar variabel dengan menggunakan perhitungan statistik.

\section{HASIL DAN PEMBAHASAN}

\section{Manajemen Sumber Daya Manusia}

Manajemen Sumber Daya Manusia merupakan salah satu cabang manajemen yang menitikberatkan pada permasalahan manusia yang mempunyai kedudukan yang utama dalam setiap perusahaan dan organisasi. Sumber Daya Manusia merupakan aset yang sangat penting bagi suatu perusahaan, walaupun perusahaan mempunyai modal yang besar, modern, namun itu tidak berarti tanpa manusia. Oleh karena itu perusahaan mengkoordinir memberi bimbingan, mengkoordinasi, mengevaluasi mereka sehingga tercipta Sumber Daya Manusia yang berkualitas. Manajemen Sumber Daya Manusia merupakan salah satu bidang manajemen untuk membentuk tenaga kerja yang efektif dan efisien.

Manajemen adalah ilmu seni yang mengatur proses pemanfaatan sumber daya manusia dan sumber daya lainnya secara efektif dan efisien untuk mencapai suatu tujuan tertentu. Manajemen sebagai ilmu, artinya pengetahuan yang digunakan untuk mencari kebenaran. Oleh karena itu untuk menjadi manajer yang baik, di samping memerlukan bakat juga harus berilmu pengetahuan,

Al Qalam: Jurnal Ilmiah Keagamaan dan Kemasyarakatan Vol. 16, No. 2

Maret - April 2022 
Rediyono, Ana Rahmiaty, Didik Cahyono : Pengaruh Belanja Langsung dan Belanka Tidak Langsung Terhadap Realisasi Anggaran dan Kinerja Instansi Pada Dinas Penanaman Modal dan Pelayanan Terpadu Satu Pintu Kabupaten Balangan Kalimantan Selatan

sedangkan di dalam manajemen diperlukan oleh para manajer untuk memilih salah satu dari beberapa alternatif pemecahan berbagai masalah bisnis dan manajemen.

Menurut Rivai Manajemen Sumber Daya Manusia (MSDM) merupakan salah satu bidang dari manajemen umum yang meliputi segi-segi perencanaan, pengorganisasian, pelaksanaan dan pengendalian".

Menurut Handoko Manajemen Sumber Daya Manusia adalah penarikan, seleksi, pengembangan, pemeliharaan, dan penggunaan sumber daya manusia untuk mencapai tujuantujuan individu maupun organisasi".

Menurut Dessler "Human Resource Management (HRM) is the policies and practices involved in carrying out the "people" or human resource aspects of management position including recruiting, screening, training, rewarding and appraising". Artinya "Manajemen Sumber Daya Manusia adalah suatu kebijakan dan praktik menentukan aspek "manusia" atau Sumber Daya Manusia dalam posisi manajemen termasuk merekrut, melatih, memberikan penghargaan dan penilaian".

\section{Fungsi Manajemen Sumber Daya Manusia}

Secara singkat fungsi-fungsi manajemen sebagai berikut :

1. Perencanaan (Planning).Merencanakan tenaga kerja secara efektif dan efisien agar sesuai dengan kebutuhan perusahaan dalam mewujudkan tujuan.

2. Pengorganisasian (Organizing).Menyusun suatu organisasi dengan mendesain struktur dan hubungan antara tugas-tugas yang harus dikerjakan oleh tenaga kerja yang dipersiapkan.

3. Pengarahan (Directing).Kegiatan mengarahkan semua karyawan agar mau bekerja sama dan bekerja secara efektif dan efisien dalam membantu tercapainya tujuan perusahaan, karyawan, dan masyarakat.

4. Pengendalian (Controlling).Kegiatan mengendalikan semua karyawan agar mentaati peraturan-peraturan perusahaan dan bekerja sesuai dengan rencana.

5. Pengadaan Tenaga Kerja (Procurement). Proses penarikan, seleksi, penempatan, orientasi, dan induksi untuk mendapatkan karyawan yang sesuai dengan kebutuhan perusahaan.

6. Pengembangan (Development).Proses peningkatan keterampilan teknis, teoritis, konseptual, dan moral karyawan melalui pendidikan dan pelatihan.

Al Qalam: Jurnal Ilmiah Keagamaan dan Kemasyarakatan Vol. 16, No. 2

Maret - April 2022 
Rediyono, Ana Rahmiaty, Didik Cahyono : Pengaruh Belanja Langsung dan Belanka Tidak Langsung Terhadap Realisasi Anggaran dan Kinerja Instansi Pada Dinas Penanaman Modal dan Pelayanan Terpadu Satu Pintu Kabupaten Balangan Kalimantan Selatan

7. Kompensasi (Compensation). Pemberian balas jasa langsung (direct), dan tidak langsung (indirect), uang atau barang kepada karyawan sebagai imbalan jasa yang diberikan kepada perusahaan.

8. Pengintegrasian (Integration). Kegiatan untuk mempersatukan kepentingan perusahaan dan kebutuhan karyawan, agar tercipta kerjasama yang serasi dan saling menguntungkan.

9. Pemeliharaan (Maintenance). Kegiatan untuk memelihara atau meningkatkan kondisi fisik, mental, dan loyalitas karyawan agar mereka mau bekerja sama sampai pensiun. Pemeliharaan yang baik dilakukan dengan program kesejahteraan yang berdasarkan sebagian besar kebutuhan karyawannya.

10. Kedisiplinan (Discipline). Keinginan dan kesadaran untuk mentaati peraturanperaturan perusahaan dan norma-norma sosial.

11. Pemutusan Hubungan Tenaga Kerja (Separation). Putusnya hubungan kerja seseorang dari suatu perusahaan. Pemutusan hubungan kerja ini dapat disebabkan oleh keinginan karyawan, keinginan perusahaan, kontrak kerja berakhir, pensiun dan sebab-sebab lainnya.

\section{Iklim Organisasi}

Perilaku individu dalam suatu organisasi dapat dipengaruhi oleh berbagai faktor, diantaranya ialah terkait dengan kondisi lingkungan kerjanya dan berbagai hal yang dirasakan oleh individu. Organisasi dalam aplikasinya menciptakan kondisi atau iklim yang bermacammacam sehingga menjadikan perilaku individu dalam organisasi tersebut menjadi dinamis ataupun statis.

\section{Dimensi Iklim Organisasi}

Ada sepuluh dimensi iklim pada tingkat organisasi secara keseluruhan. Dimensi-dimensi itu adalah:

a. Struktur tugas. Tingkat perincian metode yang dipakai untuk melakukan tugas oleh organisasi.

b. Hubungan imbalan-hukuman. Tingkat batas pemberian imbalan tambahan seperti promosi dan kenaikan gaji didasarkan pada prestasi dan jasa dan bukan pada pertimbanganpertimbangan lain seperti senioritas, favoritas, dan seterusnya.

c. Sentralisasi keputusan. Batas keputusan-keputusan penting dipusatkan pada manajemen atas.

Al Qalam: Jurnal Ilmiah Keagamaan dan Kemasyarakatan Vol. 16, No. 2

Maret - April 2022 
Rediyono, Ana Rahmiaty, Didik Cahyono : Pengaruh Belanja Langsung dan Belanka Tidak Langsung Terhadap Realisasi Anggaran dan Kinerja Instansi Pada Dinas Penanaman Modal dan Pelayanan Terpadu Satu Pintu Kabupaten Balangan Kalimantan Selatan

d. Tekanan pada prestasi. Keinginan pihak pekerja organisasi untuk melaksanakan pekerjaan dengan baik dan memberikan sumbangannya bagi sasaran karya organisasi.

e. Tekanan pada latihan dan pengembangan. Tingkat batas organisasi berusaha meningkatkan prestasi individu melalui kegiatan latihan dan pengembangan yang tepat

f. Keamanan versus resiko. Tingkat batas tekanan dalam organisasi menimbulkan perasaan kurang aman dan kecemasan pada para anggotanya.

g. Keterbukaan versus ketertutupan. Tingkat batas orang-orang lebih suka berusaha menutupi kesalahan mereka dan menampilkan diri secara baik daripada berkomunikasi secara bebas dan bekerjasama.

h. Status dan semangat. Perasaan umun diantara para individu bahwa organisasi merupakan tempat bekeria yang baik.

i. Pengakuan dan umpan balik. Tingkat batas seorang individu mengetahui apa pendapat atasannya dan manajemen mengenal pekerjaannya serta tingkat batas dukungan mereka atas dirinya.

j. Kompetensi dan keluwesan organisasi secara umum. Tingkat batas organisasi mengetahui apa tujuannya dan mengejarnya secara luwes dan kreatif Termasuk juga batas organisasi mengantisipasi masalah, mengembangkan metode baru, dan mengembangka keterampilan baru pada pekerja sebelum masalahnya menjadi gawat.

\section{Pengertian Kemampuan Kerja}

Kemampuan merupakan salah satu unsur dalam kematangan berkaitan dengan pengetahuan atau keterampilan yang dapat diperoleh dari pendidikan, pelatihan dan suatu pengalaman. Kemampuan kerja merujuk suatu fitur yang kompleks dan tingkat mencerminkan interaksi antara volume kedua kegiatan fisik dan mental dan kemampuan fungsional pekerja, kesehatan mereka dan penilaian subjektif dari status mereka dalam kondisi organisasi dan sosial yang diberikan. Kemampuan adalah sifat yang dibawa lahir atau dipelajari yang memungkinkan seseorang yang dapat menyelesaikan pekerjaannya, baik secara mental ataupun fisik.

\section{Jenis - Jenis Kemampuan Kerja}

Ada 3 jenis kemampuan dasar yang harus dimiliki untuk mendukung seseorang dalam melaksanakan pekerjaan atau tugas, sehingga tercapai hasil yang maksimal, yaitu:

1. Technical Skill (Kemampuan Teknis) Adalah pengetahuan dan penguasaan kegiatan yang bersangkutan dengan cara proses dan prosedur yang menyangkut pekerjaan dan alat-alat kerja.

Al Qalam: Jurnal Ilmiah Keagamaan dan Kemasyarakatan Vol. 16, No. 2

Maret - April 2022 
Rediyono, Ana Rahmiaty, Didik Cahyono : Pengaruh Belanja Langsung dan Belanka Tidak Langsung Terhadap Realisasi Anggaran dan Kinerja Instansi Pada Dinas Penanaman Modal dan Pelayanan Terpadu Satu Pintu Kabupaten Balangan Kalimantan Selatan

2. Human Skill (Kemampuan bersifat manusiawi) Adalah kemampuan untuk bekerja dalam kelompok suasana di mana organisasi merasa aman dan bebas untuk menyampaikan masalah.

3. Conceptual Skill (Kemampuan Konseptual) Adalah kemampuan untuk melihat gambar kasar untuk mengenali adanya unsur penting dalam situasi memahami di antara unsur-unsur itu.

\section{Cara Pengukuran Kemampuan Kerja}

Indeks Kemampuan kerja atau Work Ability Index (WAI) merupakan instrumen yang digunakan dalam klinis kesehatan kerja dan penelitian untuk menilai kemampuan kerja selama pemeriksaan kesehatan dan survei tempat kerja. Indeks ini ditentukan atas dasar jawaban atas serangkaian pertanyaan yang mempertimbangkan tuntutan pekerjaan, status kesehatan pekerja dan sumber daya.

\section{Faktor-Faktor Yang Mempengaruhi Kemampuan Kerja}

Terdapat beberapa factor yang dapat mempengaruhi kemampuan seseorang karyawan, yaitu sebagai berikut : 1) Keyakinan dan Nilai - nilai. 2) Keterampilan. 3) Pengalaman. 4) Karakteristik kepribadian. 5). Motivasi. 6) Isu emosional.

Faktor-faktor yang mempengaruhi kemampuan adalah faktor pengetahuan (kownledge) dan faktor keterampilan (skill).

1. Pengetahuan (kownledge) yaitu Informasi yang telah diproses dan diorganisasikan untuk memperoleh pemahaman, pembelajaran dan pengalaman yang terakumulasi sehingga bisa diaplikasikan ke dalam pekerjaan pegawai itu sendiri.

2. Keterampilan (skill) adalah kemampuan pegawai untuk menyelesaikan pekerjaan dengan efektif dan efisien secara teknik pelaksanaan kerja tertentu yang berkaitan dengan tugas individu dalam suatu organisasi.

\section{Dimensi dan Indikator Kemampuan Kerja}

Ada beberapa Kemampuan yang diperlukan dalam suatu instansi agar pegawai dapat mengerjakan tugas yang dibebankan padanya. beberapa kemampuan yang harus dimiliki oleh karyawan untuk mencapai efektifitas dan efisiensi kerja :

1. Kemampuan berinteraksi yang meliputi indikator: Kemampuan karyawan untuk menciptakan dan menjaga hubungan pribadi. Kemampuan karyawan untuk berkomunikasi dengan rekannya secara efektif. Kemampuan karyawan untuk menangani konflik baik dengan orang lain maupun teman sekerja. Kemampuan untuk meningkatkan atau mempertahankan rasa keadilan dan persamaan kedudukan dalam suatu system imbalan.

Al Qalam: Jurnal Ilmiah Keagamaan dan Kemasyarakatan Vol. 16, No. 2

Maret - April 2022 
Rediyono, Ana Rahmiaty, Didik Cahyono : Pengaruh Belanja Langsung dan Belanka Tidak Langsung Terhadap Realisasi Anggaran dan Kinerja Instansi Pada Dinas Penanaman Modal dan Pelayanan Terpadu Satu Pintu Kabupaten Balangan Kalimantan Selatan

2. Kemampuan konseptual (Conceptual ability). Kemampuan karyawan untuk membina dan menganalisis informasi baik dari dalam maupun dari luar lingkungan organisasi. Kemampuan untuk merefleksikan arti perubahan tersebut dalam tugas. Kemampuan untuk menentukan keputusan yang berkaitan dengan bidang tugasnya. Kemampuan untuk melakukan perubahan dalam pekerjaannya terutama yang perlu dalam organisasi.

3. Kemampuan Teknis; Kemampuan karyawan untuk mengembangkan dan mengikuti rencana-rencana kebijakan dan prosedur yang efektif. Kemampuan untuk memproses tata warkat atau kertas kerja dengan baik, teratur dan tepat waktu. . Kemampuan untuk mengelola pengeluaran atas suatu anggaran. Kemampuan untuk menggunakan pengetahuannya, peralatan-peralatan (tools), pengalaman (experience), dan teknis-teknis dari berbagai disiplin ilmu untuk memecahkan masalah.

\section{Pengertian Semangat Kerja}

Dengan semangat kerja yang tinggi merupakan suatu reaksi yang positif dengan kata lain dapat menyelesaikan pekerjaan dengan hasil yang lebih baik, maka semangat kerja mempunyai pengaruh terhadap aktivitas kantor, sehingga kantor atau organisasi menginginkan pegawai yang mempunyai semangat kerja yang tinggi.

Kata semangat (morale) itu mula mula dipergunakan dalam kalangan militer untuk menunjukkan keadaan moral pasukan, akan tetapi sekarang mempunyai arti yang lebih luas dan dapat dirumuskan sebagai sikap bersama para pekerja terhadap satu sama lain, terhadap atasan, terhadap manajemen, atau pekerjaan. Semangat kerja adalah melakukan pekerjaan secara lebih giat sehingga pekerjaan dapat diharapkan lebih cepat dan lebih baik.

Semangat kerja sebagai keinginan dan kesungguhan seseorang mengerjakan pekerjaanya dengan baik serta berdisiplin untuk mencapai prestasi kerja yang maksimal. Semangat kerja dapat diartikan sebagai suatu kondisi mental, atau perilaku individu tenaga kerja dan kelompokkelompok yang menimbulkan kesenangan yang mendalam pada diri tenaga kerja untuk bekerja dengan giat dan konsekuen dalam mencapai tujuan yang telah ditetapkan kantor.

\section{Faktor - Faktor Yang Mempengaruh Semangat Kerja}

Semangat kerja adalah istilah yang menyangkut keperluan diluar pekerjaan seperti pendapatan, rasa aman, dan kedudukan lebih tinggi dalam masyarakat, keputusan terhadap pekerjaan misalnya minat kerja, peluang untuk maju dan prestise di dalam kantor, kepuasan pribadi dan rasa bangga atas profesinya.

Faktor yang mempengaruhi semangat kerja pegawai adalah minat atau perhatian terhadap pekerjaan, upah gaji, status sosial berdasarkan jabatan, tujuan yang mulia dan pengabdian.

\section{Al Qalam: Jurnal Ilmiah Keagamaan dan Kemasyarakatan Vol. 16, No. 2}

Maret - April 2022 
Rediyono, Ana Rahmiaty, Didik Cahyono : Pengaruh Belanja Langsung dan Belanka Tidak Langsung Terhadap Realisasi Anggaran dan Kinerja Instansi Pada Dinas Penanaman Modal dan Pelayanan Terpadu Satu Pintu Kabupaten Balangan Kalimantan Selatan

\subsection{Analisis Hasil Penelitian}

\subsubsection{Uji Asumsi Klasik}

\section{Uji Multikolinieritas struktur I}

Berikut hasil uji multikolinieritas dalam penelitian ini, yaitu:

Tabel 5.6

\section{Hasil Uji Multikolinieritas Struktur I}

\begin{tabular}{|l|c|c|}
\hline \multicolumn{1}{|c|}{ Variabel Penelitian } & Tolerance & VIF \\
\hline Belanja langsung (X1) & 0,997 & 1,231 \\
\hline Belanja tidak langsung (X2) & 0,990 & 1,141 \\
\hline
\end{tabular}

Sumber: lampiran 6

Uji multikolinieritas struktur I tersebut dapat disimpulkan hasil uji multikolinieritas tidak ada gejala multikolinieritas antar variabel bebas dalam model regresi karena nilai tolerance mendekati 1 dan nilai variance inflation factor (VIF) menunjukkan tidak ada satu pun variabel bebas yang memiliki nilai VIF lebih dari 10.

\section{Uji Heteroskedastisitas Struktur I}

Kemudian uji asumsi klasik kedua yaitu uji heteroskedastisitas struktur I dapat digambarkan sebagai berikut:

\section{Scatterplot}

Dependent Variable: Realisasi Anggaran (Z)

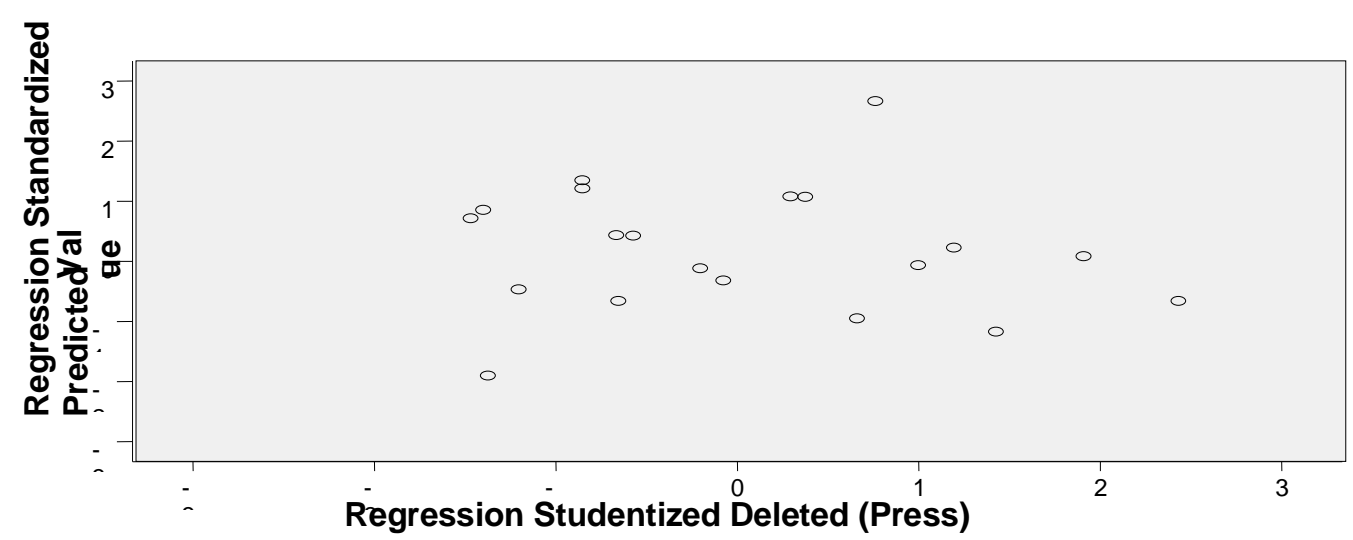

Gambar 5.2 : Scatterplot Struktur I

Al Qalam: Jurnal Ilmiah Keagamaan dan Kemasyarakatan Vol. 16, No. 2

Maret - April 2022 
Rediyono, Ana Rahmiaty, Didik Cahyono : Pengaruh Belanja Langsung dan Belanka Tidak Langsung Terhadap Realisasi Anggaran dan Kinerja Instansi Pada Dinas Penanaman Modal dan Pelayanan Terpadu Satu Pintu Kabupaten Balangan Kalimantan Selatan

Sumber : lampiran 6

Hasil uji heteroskedastisitas struktur I melalui analisis grafik scatterplots di atas ini terlihat titik-titik menyebar secara acak serta tersebar baik di atas maupun di bawah angka 0 pada sumbu Y. Hal ini dapat disimpulkan bahwa tidak terjadi heteroskedastisitas pada model regresi, sehingga model regresi layak dipakai untuk memprediksi variabel terikat berdasarkan pengaruh variabel bebas.

\section{Uji Normalitas struktur I}

Uji Asumsi klasik ketiga untuk struktur I, adapun hasil dari uji normalitas dalam penelitian ini, yaitu:

\section{Normal P-P Plot of Regression Standardized Residual}

\section{Dependent Variable: Realisasi Anggaran (Z)}

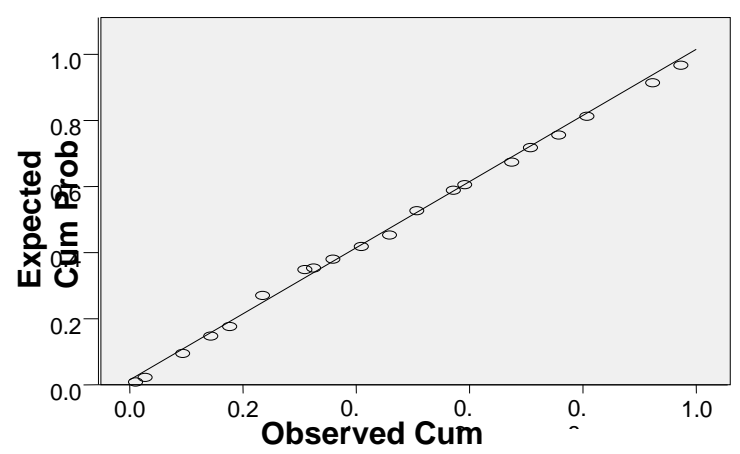

Gambar 5.3 Diagram Normal P-P Plot Struktur I

Sumber: lampiran 6

Hasil uji normalitas struktur I menunjukkan bahwa grafik terlihat titik-titik menyebar disekitar garis diagonal, serta penyebarannya mengikuti arah garis diagonal, ini menunjukkan bahwa model regresi layak dipakai untuk memprediksi variabel dependen berdasarkan masukan dari variabel independen, karena memenuhi uji asumsi normalitas.

\section{Uji Autokorelasi Struktur I}

Untuk mendeteksi ada atau tidak adanya autokorelasi pada penelitian ini menggunakan uji Durbin-Watson (DW test), adapun hasil uji otokorelasi dalam penelitian ini adalah Nilai uji Durbin Watson (DW) sebesar 2,275 masuk dalam nilai DW antara 1,55 s.d 2,45 (mendekati 2), dapat disimpulkan bahwa tidak terdapat otokorelasi antara variabel bebas dengan variabel terikat.

\section{Uji Multikolinieritas struktur II}

Berikut hasil uji multikolinieritas dalam penelitian ini, yaitu:

Al Qalam: Jurnal Ilmiah Keagamaan dan Kemasyarakatan Vol. 16, No. 2

Maret - April 2022 
Rediyono, Ana Rahmiaty, Didik Cahyono : Pengaruh Belanja Langsung dan Belanka Tidak Langsung Terhadap Realisasi Anggaran dan Kinerja Instansi Pada Dinas Penanaman Modal dan Pelayanan Terpadu Satu Pintu Kabupaten Balangan Kalimantan Selatan

Tabel 5.7

\section{Hasil Uji Multikolinieritas Struktur II}

\begin{tabular}{|l|c|c|}
\hline \multicolumn{1}{|c|}{ Variabel Penelitian } & Tolerance & VIF \\
\hline Belanja langsung (X1) & 0,987 & 1,162 \\
\hline Belanja tidak langsung (X2) & 0,969 & 1,119 \\
\hline Realisasi anggaran (Z) & 0,998 & 1,213 \\
\hline
\end{tabular}

Sumber: lampiran 6

Disimpulkan hasil uji multikolinieritas struktur II tidak ada gejala multikolinieritas antar variabel bebas, perantara ke variabel terikat dalam model regresi karena nilai tolerance mendekati 1 dan nilai variance inflation factor (VIF) menunjukkan tidak ada satu pun variabel bebas dan perantara yang memiliki nilai VIF lebih dari 10.

\section{Uji Heteroskedastisitas Struktur II}

Berikut hasil uji heteroskedastisitas dapat digambarkan sebagai berikut:

Scatterplot

Dependent Variable: Kinerja Instansi (Y)

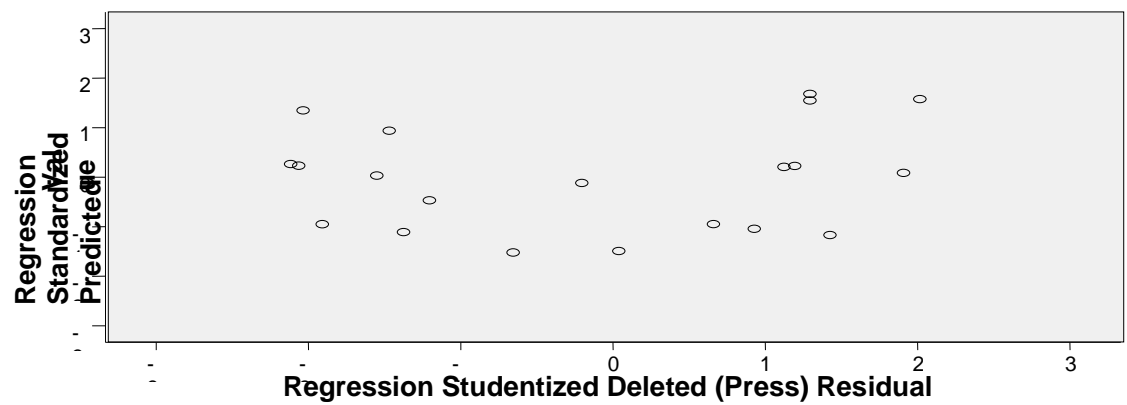

Gambar 5.4 : Scatterplot Struktur II

Sumber : lampiran 6

Hasil uji heteroskedastisitas struktur II melalui grafik scatterplots di atas ini terlihat titik-titik menyebar secara acak serta tersebar baik di atas maupun di bawah angka 0 pada sumbu Y. Hal ini dapat disimpulkan bahwa tidak terjadi heteroskedastisitas pada model regresi, sehingga model regresi layak dipakai untuk memprediksi variabel terikat berdasarkan pengaruh variabel bebas dan perantara.

\section{Uji Normalitas struktur II}

Hasil uji normalitas struktur II dalam penelitian ini, dapat digambarkan, sebaiak berikut:

Al Qalam: Jurnal Ilmiah Keagamaan dan Kemasyarakatan Vol. 16, No. 2

Maret - April 2022 
Rediyono, Ana Rahmiaty, Didik Cahyono : Pengaruh Belanja Langsung dan Belanka Tidak Langsung Terhadap Realisasi Anggaran dan Kinerja Instansi Pada Dinas Penanaman Modal dan Pelayanan Terpadu Satu Pintu Kabupaten Balangan Kalimantan Selatan

\section{Normal P-P Plot of Regression Standardized Residual \\ Dependent Variable: Kinerja Instansi $(Y)$}

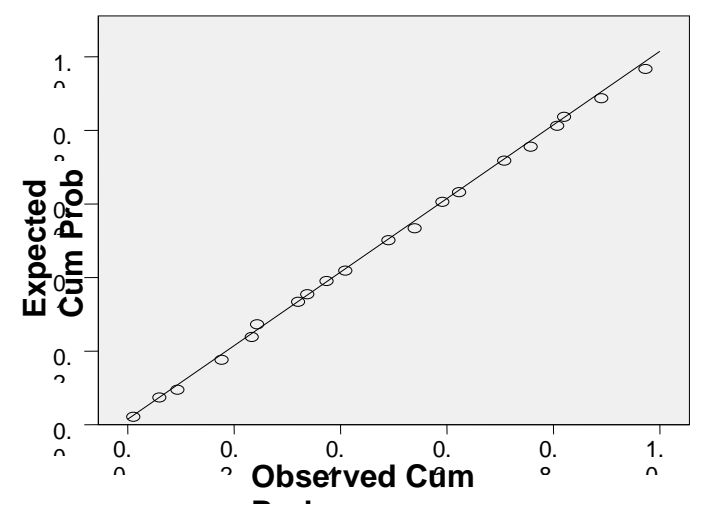

Gambar 5.5 Diagram Normal P-P Plot Struktur II

Sumber: lampiran 6

Hasil uji normalitas struktu II menunjukkan bahwa grafik terlihat titik-titik menyebar disekitar garis diagonal, serta penyebarannya mengikuti arah garis diagonal, ini menunjukkan bahwa model regresi layak dipakai untuk memprediksi variabel dependen berdasarkan masukan dari variabel independen dan perantara, karena memenuhi uji asumsi normalitas.

\section{Uji Autokorelasi Struktur II}

Untuk mendeteksi ada atau tidak adanya autokorelasi pada penelitian ini menggunakan uji Durbin-Watson (DW test), adapun hasil uji otokorelasi dalam penelitian ini adalah Nilai uji Durbin Watson (DW) sebesar 2,288 masuk dalam nilai DW antara 1,55 s.d 2,45 (mendekati 2), dapat disimpulkan bahwa tidak terdapat otokorelasi antara variabel bebas dengan variabel terikat.

\subsubsection{Analisis Regresi Berganda}

\section{Uji Hipotesis Struktur I}

Analisis path dalam penelitian ini menggunakan uji regresi berganda melalui program spss, berikut ini rekapitulasi hasil regresi berganda, yaitu:

Tabel 5.8

Analisis Path Metode Regresi Berganda Uji Struktur I

(variabel X1 dan X2 terhadap Z)

Coefficients(a)

\begin{tabular}{|l|l|l|l|l|l|l|}
\hline Model & Unstandardized & Standardized & $\mathrm{t}$ & Sig. & Correlations & Collinearity \\
\hline
\end{tabular}

Al Qalam: Jurnal Ilmiah Keagamaan dan Kemasyarakatan Vol. 16, No. 2

Maret - April 2022 
Rediyono, Ana Rahmiaty, Didik Cahyono : Pengaruh Belanja Langsung dan Belanka Tidak Langsung Terhadap Realisasi Anggaran dan Kinerja Instansi Pada Dinas Penanaman Modal dan Pelayanan Terpadu Satu Pintu Kabupaten Balangan Kalimantan Selatan

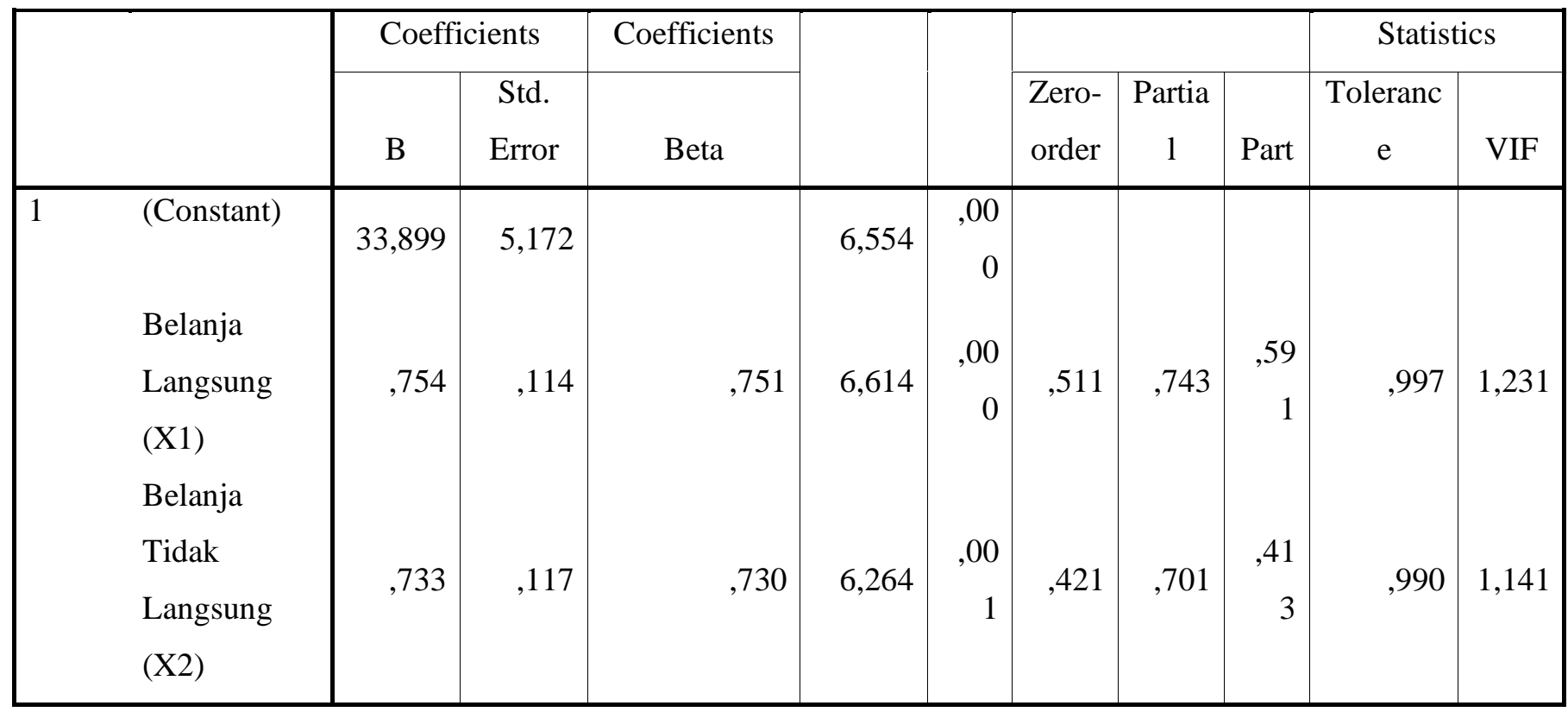

a Dependent Variable: Realisasi Anggaran (Z)

Sumber: lampiran 6

Analisis struktur I disusun persamaan struktural untuk model analisis path, yaitu:

$$
\mathrm{Z}=33,899+0,754 \mathrm{X} 1+0,733 \mathrm{X} 2+\mathrm{e} 1 \rightarrow \mathrm{e} 1=(1-0,853)^{2}
$$

Berdasarkan data tersebut, maka dapat disusun persamaan structural penelitian struktur I, yaitu:

a = nilai constanta sebesar 33,899 artinya jika variabel belanja langsung dan belanja tidak langsung nilainya adalah nol (0), maka realisasi anggaran akan naik sebesar 33,899.

$\mathrm{b}_{1} \quad=$ mempunyai nilai 0,754 mengandung arti bahwa variabel belanja langsung ditingkatkan satu satuan, maka tingkat realisasi anggaran akan meningkat sebesar $75,4 \%$, dengan asumsi variabel lain konstan.

$\mathrm{b}_{2} \quad=$ mempunyai nilai 0,733 , artinya bahwa variabel belanja tidak langsung ditingkatkan satu satuan, maka tingkat realisasi anggaran meningkat sebesar 73,3\%, dengan asumsi variabel lain konstan.

$\mathrm{R}^{2}=$ besarnya koefisien determinan $\mathrm{R}^{2}$ terhadap struktur pertama adalah sebesar 0,853 .

Langkah selanjutnya adalah uji hipotesis. Untuk mengetahui akan pengujian hipotesis pertama secara parsial terlebih dahulu harus diketahui akan ttabel dengan cara mendapatkan ttabel digunakan tabel distribusi t untuk tingkat signifikasi 5\% dengan Degrees of Freedom $(\mathrm{df})=\mathrm{n}-\mathrm{k}$ maka di dapat df adalah (20-3)= 17 dengan demikian ttabel adalah sebesar 1,740.

Pengujian hipotesis untuk struktur I yaitu hipotesis pertama dan hipotesis kedua dalam penelitian ini dapat dijelaskan :

Al Qalam: Jurnal Ilmiah Keagamaan dan Kemasyarakatan Vol. 16, No. 2

Maret - April 2022 
Rediyono, Ana Rahmiaty, Didik Cahyono : Pengaruh Belanja Langsung dan Belanka Tidak Langsung Terhadap Realisasi Anggaran dan Kinerja Instansi Pada Dinas Penanaman Modal dan Pelayanan Terpadu Satu Pintu Kabupaten Balangan Kalimantan Selatan

\section{Pengujian Hipotesis Pertama}

Belanja langsung berpengaruh signifikan terhadap realisasi anggaran pada Dinas Penanaman Modal dan Pelayanan Terpadu Satu Pintu Kabupaten Balangan Kalimantan Selatan

Variabel belanja langsung (X1) mempunyai pengaruh signifikan dan positif terhadap realisasi anggaran $(\mathrm{Z})$, dimana thitung lebih besar dari ttabel seperti thitung $=6,614>$ ttabel $=$ 1,740 dengan signifikasi $\mathrm{P}=0,000<0,05$. Besar pengaruh langsung antara variable belanja langsung (X1) terhadap realisasi anggaran (Z), hal itu dapat dilihat dari nilai beta atau Standardized Coefficient yaitu sebesar 0,751, yang artinya belanja langsung (X1) mempunyai pengaruh signifikan secara langsung terhadap realisasi anggaran $(Z)$ sebesar 75,1\%.

\section{Pengujian Hipotesis Kedua (H2)}

Belanja tidak langsung berpengaruh signifikan terhadap realisasi anggaran pada Dinas Penanaman Modal dan Pelayanan Terpadu Satu Pintu Kabupaten Balangan Kalimantan Selatan

Variabel belanja tidak langsung (X2) mempunyai pengaruh signifikan dan positif terhadap realisasi anggaran $(\mathrm{Z})$, dimana thitung lebih besar dari ttabel seperti thitung $=6,264>$ ttabel $=1,740$ dengan signifikasi $\mathrm{P}=0,001<0,05$. Besar pengaruh langsung antara variable belanja tidak langsung (X2) terhadap variabel realisasi anggaran (Z), hal itu dapat dilihat dari nilai beta atau Standardized Coefficient yaitu sebesar 0,730, yang artinya belanja tidak langsung (X2) mempunyai pengaruh signifikan secara langsung terhadap realisasi anggaran $(Z)$ sebesar $73 \%$.

\section{Uji Hipotesis Struktur II}

Setelah selesai pengujian struktut I selanjutnya adalah pembuktian hipotesis struktur II, berikut ini yang telah diajukan beserta analisis penelitian ini dari hasil pengolahan data, yaitu:

Tabel 5.9

\section{Analisis Path Metode Regresi BergandaUji Struktur II}

(variabel X1,X2, Z terhadap Y)

Coefficients(a)

\begin{tabular}{|c|c|c|c|c|c|c|c|c|c|c|}
\hline \multirow[b]{2}{*}{ Model } & \multicolumn{2}{|c|}{$\begin{array}{c}\text { Unstandardized } \\
\text { Coefficients }\end{array}$} & \multirow{2}{*}{$\begin{array}{c}\begin{array}{c}\text { Standardized } \\
\text { Coefficients }\end{array} \\
\text { Beta }\end{array}$} & \multirow[b]{2}{*}{$\mathrm{T}$} & \multirow[b]{2}{*}{ Sig. } & \multicolumn{3}{|c|}{ Correlations } & \multicolumn{2}{|c|}{$\begin{array}{c}\text { Collinearity } \\
\text { Statistics }\end{array}$} \\
\hline & $\mathrm{B}$ & $\begin{array}{l}\text { Std. } \\
\text { Error }\end{array}$ & & & & $\begin{array}{l}\text { Zero- } \\
\text { order }\end{array}$ & $\begin{array}{c}\text { Partia } \\
1\end{array}$ & Part & $\begin{array}{c}\text { Toleranc } \\
\mathrm{e}\end{array}$ & VIF \\
\hline $1 \quad$ (Constant) & 25,245 & 7,230 & & 3,491 & $\begin{array}{r}, 00 \\
4\end{array}$ & & & & & \\
\hline Belanja & ,791 &, 122 &, 790 & 6,483 &, 00 &, 442 & ,788 &, 53 & ,987 & 1,162 \\
\hline
\end{tabular}

Al Qalam: Jurnal Ilmiah Keagamaan dan Kemasyarakatan Vol. 16, No. 2

Maret - April 2022 
Rediyono, Ana Rahmiaty, Didik Cahyono : Pengaruh Belanja Langsung dan Belanka Tidak Langsung Terhadap Realisasi Anggaran dan Kinerja Instansi Pada Dinas Penanaman Modal dan Pelayanan Terpadu Satu Pintu Kabupaten Balangan Kalimantan Selatan

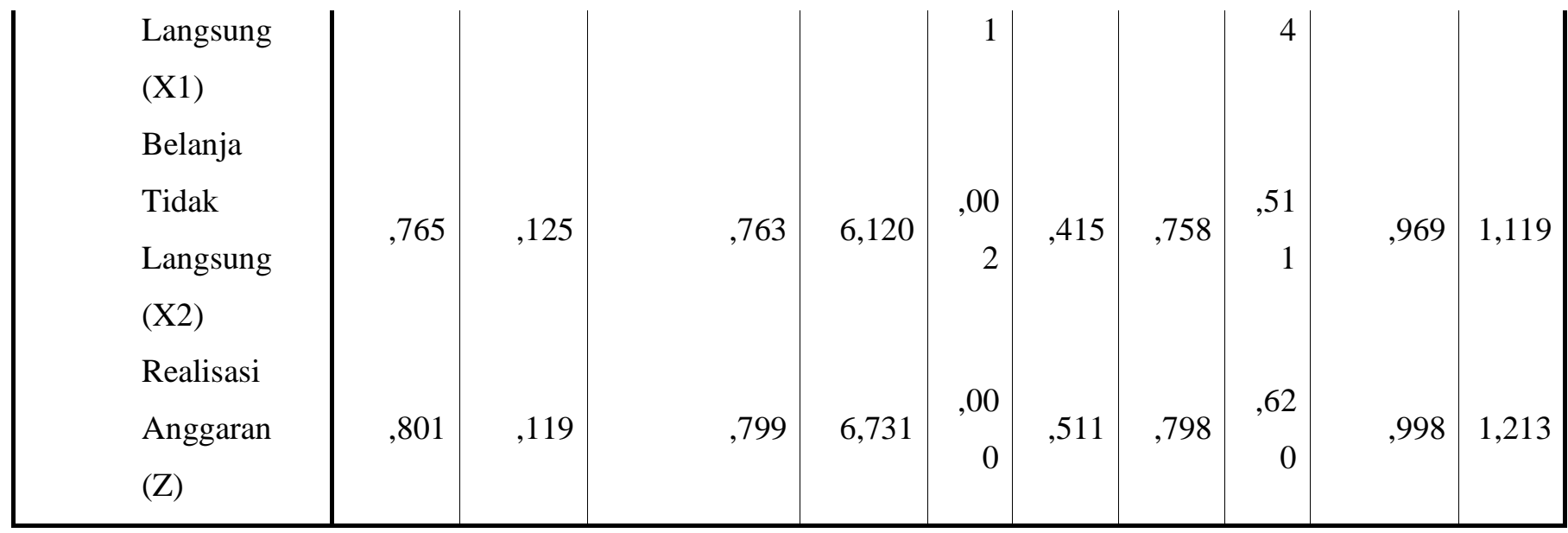

a Dependent Variable: Kinerja Instansi (Y)

Sumber : lampiran 6

Analisis struktur II disusun persamaan struktural untuk model analisis path, yaitu:

$$
\mathrm{Y}=25,245+0,791 \mathrm{X} 1+0,765 \mathrm{X} 2+0,801 \mathrm{Z}+\mathrm{e} 2 \rightarrow \mathrm{e} 2=(1-0,811)^{2}
$$

Berdasarkan persamaan struktural tersebut, dapat digambarkan regresi linier, yaitu:

a = nilai constanta sebesar 25,245 artinya jika variabel belanja langsung dan belanja tidak langsung nilainya serta reasliasi anggaran adalah nol (0), maka kinerja instansi akan naik sebesar 25,245.

$\mathrm{b}_{1} \quad=$ mempunyai nilai 0,791 mengandung arti bahwa variabel belanja langsung ditingkatkan satu satuan, maka tingkat kinerja instansi akan meningkat sebesar 79,1\%, dengan asumsi variabel lain konstan.

$\mathrm{b}_{2} \quad=$ mempunyai nilai 0,765 , artinya bahwa variabel belanja tidak langsung ditingkatkan satu satuan, maka tingkat kinerja instansi meningkat sebesar 76,5\%, dengan asumsi variabel lain konstan.

$\mathrm{Z} \quad=$ mempunyai nilai 0,801 , artinya bahwa variabel realisasi ditingkatkan satu satuan, maka tingkat kinerja instansi meningkat sebesar $80,1 \%$, dengan asumsi variabel lain konstan.

$\mathrm{R}^{2}=$ besarnya koefisien determinan $\mathrm{R}^{2}$ terhadap struktur pertama adalah sebesar 0,811

Menilai hubungan linier antar variabel dapat dilakukan membandingkan nilai thitung dengan langkah penentuan taraf signifikasi 0,05 dan derajat kebebasan (DK). Cara dengan membandingkan nilai thitung dengan ttable pada taraf nyata 5\%. Jika thitung $>$ t table maka pengaruhnya signifikan. Untuk mendapatkan ttabel digunakan tabel distribusi t signifikasi 5\% dengan Degrees of Freedom $(\mathrm{df})=\mathrm{n}-\mathrm{k}$ maka d df adalah (20-4)=16 dengan demikian ttabel adalah sebesar 1,764 .

Al Qalam: Jurnal Ilmiah Keagamaan dan Kemasyarakatan Vol. 16, No. 2

Maret - April 2022 
Rediyono, Ana Rahmiaty, Didik Cahyono : Pengaruh Belanja Langsung dan Belanka Tidak Langsung Terhadap Realisasi Anggaran dan Kinerja Instansi Pada Dinas Penanaman Modal dan Pelayanan Terpadu Satu Pintu Kabupaten Balangan Kalimantan Selatan

Berdasarkan data tersebut dapat digambarkan hasil pengujian hipotesis untuk struktur II yaitu hipotesis ketiga, hipotesis keempat sampai dengan hipotesis kelima, dapat dijelaskan sebagai berikut :

\section{1) Pengujian Hipotesis Ketiga (H3)}

Belanja langsung berpengaruh signifikan terhadap kinerja instansi pada Dinas Penanaman Modal dan Pelayanan Terpadu Satu Pintu Kabupaten Balangan Kalimantan Selatan

Hasil pengujian hipotesis ketiga menunjukkan bahwa variable belanja langsung (X1) berpengaruh langsung terhadap kinerja instansi (Y), dimana thitung lebih besar dari ttabel (thitung $=6,483>$ ttabel $=1,764)$, dengan signifikasi $\mathrm{P}=0,001<0,05$.

Besar pengaruh langsung antara variabel belanja langsung (X1) terhadap variabel kinerja instansi (Y), hal itu dapat dilihat dari nilai beta atau Standardized Coefficient yaitu sebesar 0,790 yang belanja langsung mempunyai pengaruh signifikan secara langsung terhadap kinerja instansi sebesar $79 \%$.

\section{2) Pengujian Hipotesis Keempat (H4)}

Belanja tidak langsung berpengaruh signifikan terhadap kinerja instansi pada Dinas Penanaman Modal dan Pelayanan Terpadu Satu Pintu Kabupaten Balangan Kalimantan Selatan.

Hasil pengujian hipotesis keempat menunjukkan bahwa variabel belanja tidak langsung (X2) berpengaruh langsung terhadap kinerja instansi $(\mathrm{Y})$, dimana thitung lebih besar dari ttabel (thitung $=6,120>$ ttabel $=1,764$ ), dengan signifikasi $\mathrm{P}=0,002<0,05$.

Besar pengaruh langsung antara variabel belanja tidak langsung (X2) terhadap variabel kinerja instansi (Y), hal itu dapat dilihat dari nilai beta atau Standardized Coefficient yaitu sebesar 0,763 , artinya belanja tidak langsung (X2) mempunyai pengaruh signifikan secara langsung terhadap kinerja instansi sebesar 76,3\%.

\section{3) Pengujian Hipotesis Kelima (H5)}

Realisasi anggaran berpengaruh signifikan terhadap kinerja instansi pada Dinas Penanaman Modal dan Pelayanan Terpadu Satu Pintu Kabupaten Balangan Kalimantan Selatan

Hasil pengujian hipotesis kelima menunjukkan bahwa variabel realisasi anggaran (Z) berpengaruh langsung terhadap kinerja instansi (Y), dimana thitung lebih besar dari ttabel (thitung $=6,731>$ ttabel $=1,764)$, dengan signifikasi $\mathrm{P}=0,000<0,05$.

Besar pengaruh langsung antara variabel realisasi anggaran $(Z)$ terhadap variabel kinerja instansi (Y), hal itu dapat dilihat dari nilai beta atau Standardized Coefficient yaitu sebesar 0,799, artinya realisasi anggaran $(Z)$ mempunyai pengaruh signifikan secara langsung terhadap kinerja instansi (Y) sebesar 79,9\%.

Al Qalam: Jurnal Ilmiah Keagamaan dan Kemasyarakatan Vol. 16, No. 2 Maret - April 2022 
Rediyono, Ana Rahmiaty, Didik Cahyono : Pengaruh Belanja Langsung dan Belanka Tidak Langsung Terhadap Realisasi Anggaran dan Kinerja Instansi Pada Dinas Penanaman Modal dan Pelayanan Terpadu Satu Pintu Kabupaten Balangan Kalimantan Selatan

\section{Pengujian Determinasi}

Selanjutnya dapat dilakukan pengaruh variabel bebas terhadap variabel terikat ditunjukkan oleh koefisien determinasi simultan. Untuk melihat besar keofesien diterminan dapat dilihat dari nilai $R$ Square yang mana untuk struktur $\mathrm{I} \mathrm{R}^{2}$ sebesar 0,853 dan struktur kedua nilai $\mathrm{R}^{2}$ sebesar 0,811 disini bisa dijelaskan, bahwa :

$$
\begin{aligned}
& \epsilon _ { 1 } = 1 - 0 \longdiv { 8 5 3 = 0 , 1 4 7 } \\
& \epsilon_{2}=1-Q .811=0,189 \\
& R^{2}=1-(0,147)^{2} \times(0,189)^{2} \\
& R^{2}=1-0,0216 \times 0,0357 \\
& R^{2}=1-0,00077 \\
& R^{2}=0,9992
\end{aligned}
$$

Angka dibulatkan menjadi 0,99 mempunyai makna sebagian besarnya variabel bebas (X) dan perantara $(\mathrm{Z})$ mempunyai pengaruh signifikan terhadap variabel terikat $(\mathrm{Y})$ karena nilai $\mathrm{R}^{2}$ yakni 0,99 mendekati nilai 1

\section{Pengujian Secara Langsung Dari Masing-Masing Variabel}

Pengaruh langsung (direct effect) antara variabel belanja langsung (X1 dan belanja tidak langsung (X2) terhadap realisasi anggaran (Z) maupun terhadap kinerja instasi (Y), dapat disusun sebagai berikut:

1) Pengaruh $X 1$ terhadap $Z: 0,751$ atau $75,1 \%$

2) Pengaruh $X 2$ terhadap $Z: 0,730$ atau $73 \%$

3) Pengaruh $X 1$ terhadap $Y$ : 0,790 atau 79\%

4) Pengaruh $X 2$ terhadap $Y: 0,763$ atau $76,3 \%$

5) Pengaruh $Z$ terhadap $Y \quad: 0,799$ atau $79,9 \%$

\section{Pengujian Tidak Langsung Dari Masing-Masing Variabel}

Pengaruh tidak langsung (Indirect Effect atau IE) terkait dengan variabel belanja langsung (X1) dan belanja tidak langsung (X2) terhadap kinerja instansi (Y) melalui realisasi anggaran (Z), yaitu sebagai berikut:

(1) Untuk melihat besar pengaruh tidak langung dari variabel bebas $\mathrm{X} 1$ terhadap variabel terikat $\mathrm{Y}$ melalui intervening $\mathrm{Z}$, dapat diperhitungkan sebagai berikut:

$$
\mathrm{PYX}_{1} \times \mathrm{PZY}=(0,751 \times 0,799)=0,600
$$

Berdasarkan perhitungan tersebut dapat disimpulkan bahwa pengaruh tidak langung dari variabel bebas $\mathrm{X} 1$ terhadap variabel terikat $\mathrm{Y}$ melalui intervening $\mathrm{Z}$ adalah sebesar $60 \%$

Al Qalam: Jurnal Ilmiah Keagamaan dan Kemasyarakatan Vol. 16, No. 2

Maret - April 2022 
Rediyono, Ana Rahmiaty, Didik Cahyono : Pengaruh Belanja Langsung dan Belanka Tidak Langsung Terhadap Realisasi Anggaran dan Kinerja Instansi Pada Dinas Penanaman Modal dan Pelayanan Terpadu Satu Pintu Kabupaten Balangan Kalimantan Selatan

(2) Untuk melihat besar pengaruh tidak langung dari variabel bebas $\mathrm{X} 2$ terhadap variabel terikat $\mathrm{Y}$ melalui intervening $\mathrm{Z}$, dapat diperhitungkan sebagai berikut:

$\mathrm{PYX}_{2} \times \mathrm{PYZ}=(0,730 \times 0,799)=0,583$

Berdasarkan perhitungan tersebut dapat disimpulkan bahwa pengaruh tidak langung dari variabel bebas $\mathrm{X} 2$ terhadap variabel terikat $\mathrm{Y}$ melalui variabel intervening $\mathrm{Z}$ adalah sebesar 58,3\% .

Berdasarkan perhitungan tersebut, maka dapat gambarkan model diagram jalurnya sebagai berikut:

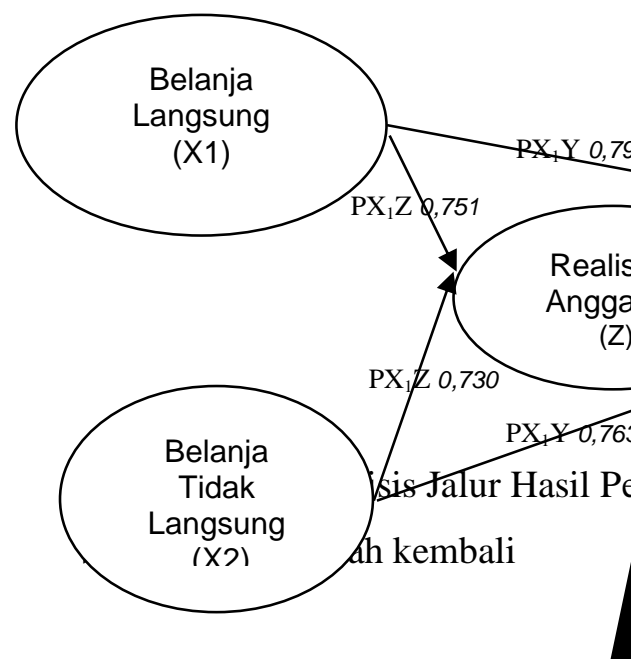

\subsection{Pembahasan}

1. Belanja langsung berpengaruh signifik Modal dan Pelayanan Terpadu Satu Pin Hasil penelitian diketahui realisasi anggaran pada Dinas Penan Balangan Kalimantan Selatan. pen Meviana Susilowati, yang menyatak signifikan terhadap realisasi angga 2006, belanja diklasifikasikan belanja langsung. Kelompok bel terkait secara langsung dengan merupakan belanja yang diang kegiatan.

${ }^{4}$ Meviana Susilowati, dan Kinerja Instansi Pemerintd

Al Qalam: Jurna 
Rediyono, Ana Rahmiaty, Didik Cahyono : Pengaruh Belanja Langsung dan Belanka Tidak Langsung Terhadap Realisasi Anggaran dan Kinerja Instansi Pada Dinas Penanaman Modal dan Pelayanan Terpadu Satu Pintu Kabupaten Balangan Kalimantan Selatan

Sejalan dengan uraian tersebut, maka Dinas Penanaman Modal dan Pelayanan Terpadu Satu Pintu Kabupaten Balangan Kalimantan Selatan dapat lebih efektif lagi dalam mengelola anggaran belanja langsung agar realisasi anggaran dapat terpenuhi sesuai dengan kebutuhan dengan terpenuhinya realisasi anggaran, maka perkembangan aktifitas pelayanan dapat ditingkatkan kemudian pengembangan iklim dan promosi penanaman modal, pengendalian pelaksanaan penanaman modal dan informasi penanaman modal, penyelenggaraan pelayanan perizinan dan non perizinan, dan pengaduan kebijakan dan pelaporan layanan, karena dapat dipenuh dan didukung oleh anggaran belanja langsug yang dikelola dengan tepat.

2. Belanja tidak langsung berpengaruh signifikan terhadap realisasi anggaran pada Dinas Penanaman Modal dan Pelayanan Terpadu Satu Pintu Kabupaten Balangan Kalimantan Selatan

Hasil penelitian diketahui bahwa belanja tidak langsung berpengaruh signifikan terhadap realisasi anggaran pada Dinas Penanaman Modal dan Pelayanan Terpadu Satu Pintu Kabupaten Balangan Kalimantan Selatan, penelitian ini sejalan pula dengan penelitian yang dilakukan oleh Meviana Susilowati, 2012 yang menyatakan dalam penelitiannya bahwa Belanja Langsung Tidak Langsung berpangaruh secara langsung terhadap realisasi anggaran. ${ }^{5}$ Selain itu juga Permendagri 13 Tahun 2006, belanja diklasifikasikan berdasarkan jenis belanja sebagai belanja tidak langsung dan belanja langsung. Kelompok belanja tidak langsung merupakan belanja yang dianggarkan tidak terkait secara langsung dengan pelaksanaan program dan kegiatan. Kelompok belanja langsung merupakan belanja yang dianggarkan terkait secara langsung dengan pelaksanaan program dan kegiatan.

Sejalan dengan uraian tersebut, maka pihak institusi dapat lebih efektif lagi dalam mengelola anggaran belanja langsung agar realisasi anggaran dapat terpenuhi sesuai dengan kebutuhan, dengan terpenuhinya realisasi anggaran, maka peningkatan perkembangan kegiatan instansi dapat dijalankan sesuai dengan program kerja yang telah ditetapkan.

3. Belanja langsung berpengaruh signifikan terhadap kinerja instansi pada Dinas Penanaman Modal dan Pelayanan Terpadu Satu Pintu Kabupaten Balangan Kalimantan Selatan.

Hasil penelitian diketahui bahwa belanja langsung berpengaruh signifikan terhadap kinerja instansi pada Dinas Penanaman Modal dan Pelayanan Terpadu Satu Pintu Kabupaten Balangan Kalimantan Selatan, penelitian ini sejalan pula dengan penelitian yang dilakukan oleh Rudie Noor Salam yang menyatakan dalam penelitiannya bahwa belanja langsung berpengaruh

${ }^{5}$ Susilowati, Analisis Pengaruh Belanja Daerah Terhadap Capaian realisasi anggaran dan Kinerja Instansi Pemerintah (Studi Kasus Pada SKPD Di Boyolali.

Al Qalam: Jurnal Ilmiah Keagamaan dan Kemasyarakatan Vol. 16, No. 2

Maret - April 2022 
Rediyono, Ana Rahmiaty, Didik Cahyono : Pengaruh Belanja Langsung dan Belanka Tidak Langsung Terhadap Realisasi Anggaran dan Kinerja Instansi Pada Dinas Penanaman Modal dan Pelayanan Terpadu Satu Pintu Kabupaten Balangan Kalimantan Selatan

signifikan terhadap kinerja instansi. ${ }^{6}$ Dan hasil penelitian ini pun terdukung oleh teori yang dikemukakan Fadli yaitu belanja langsung merupakan belanja yang dianggarkan terkait secara langsung dengan pelaksanaan program kegiatan. ${ }^{7}$ Belanja langsung merupakan belanja yang dipengaruhi secara langsung oleh adanya program atau kegiatan satuan kerja unit daerah yang kontribusinya terhadap pencapaian prestasi kerja dapat diukur. Jenis belanja langsung terdiri belanja pegawai, belanja barang dan jasa, dan belanja modal. Belanja pegawai dan belanja barang dan jasa dianggarkan untuk kegiatan yang keluaranya tidak menambah asset daerah. Belanja modal dianggarkan untuk kegiatan yang keluaranya menambah aset daerah. Belanja pegawai, belanja barang dan jasa, belanja modal dapat dianggarkan secara sekaligus untuk mendanai kegiatan dalam rangka mencapai prestasi kerja yang ditetapkan

Sejalan dengan hal tersebut dalam rangka membiaya dan memenuhi kebutuhan belanja tersebut hendaknya Dinas Penanaman Modal dan Pelayanan Terpadu Satu Pintu Kabupaten Balangan Kalimantan Selatan dapat lebih baik lagi dalam mengelola anggaran belanja khusus untuk kebutuhan yang berhubungan langsung kegiatan operaisonal organisasi, misalnya pemenuhan anggaran untuk perbaikan kantor, atau pembelian peratan kantor yang mana selama ini masih ada peralatan dan perlengkapan kantor yang sudah usang dan kurang layak dipakai serta kadang menghambat jalannya pekerjaan, untuk itu pengelolaan anggran belanja langsung harus dapat dioptimalkan agar hal-hal yang dirasakan kurang seperti adanya fasillitas yang sudah tidak layak tadi dapat diperbaharui sesuai denan anggaran belanja yang ada.

4. Belanja tidak langsung berpengaruh signifikan terhadap kinerja instansi pada Dinas Penanaman Modal dan Pelayanan Terpadu Satu Pintu Kabupaten Balangan Kalimantan Selatan

Hasil penelitian diketahui bahwa belanja tidak langsung berpengaruh signifikan terhadap kinerja instansi pada Dinas Penanaman Modal dan Pelayanan Terpadu Satu Pintu Kabupaten Balangan Kalimantan Selatan, penelitian ini sejalan pula dengan penelitian yang dilakukan oleh Rudie Noor Salam yang menyatakan dalam penelitiannya bahwa belanja tidak langsung berpengaruh signifikan terhadap kinerja instansi. ${ }^{8}$ Sejalan dengan pendapat Vegirawati yang menyatakan belanja tidak langsung merupakan belanja yang tidak dipengaruhi secara langsung oleh program atau kegiatan satuan kerja perangkat daerah yang pengaruh kontribusinya

\footnotetext{
${ }^{6}$ Rudie Noor Salam, Pengaruh Belanja Langsung Dan Belanja Tidak Langsung Terhadap Kinerja Instansi Pada Dinas Pendidikan Kabupaten Balangan (Banjarmasin: STIEPAN, 2019).

${ }^{7}$ Hendra Fadli, Anggaran Berbasis Kinerja Penyusunan APBD Secara Komprehensif (Yogyakarta: UPP STIM YKPN, 2013), 110.

${ }^{8}$ Salam, Pengaruh Belanja Langsung Dan Belanja Tidak Langsung Terhadap Kinerja Instansi Pada Dinas Pendidikan Kabupaten Balangan.
}

Al Qalam: Jurnal Ilmiah Keagamaan dan Kemasyarakatan Vol. 16, No. 2 Maret - April 2022 
Rediyono, Ana Rahmiaty, Didik Cahyono : Pengaruh Belanja Langsung dan Belanka Tidak Langsung Terhadap Realisasi Anggaran dan Kinerja Instansi Pada Dinas Penanaman Modal dan Pelayanan Terpadu Satu Pintu Kabupaten Balangan Kalimantan Selatan

terhadap pencapaian prestasi kerja sulit diukur. ${ }^{9}$ Penganggaran belanja tidak langsung mempertimbangkan asas ekonomis, efisien, dan efektif. Jenis belanja yang termasuk dalam belanja tidak langsung terdiri: belanja pegawai, belanja bunga, subsidi, hibah, bantuan sosial, belanja bagi hasil, bantuan keuangan, belanja barang dan jasa, belanja tak terduga. Belanja tidak langsung pada dasarnya merupakan belanja yang digunakan secara bersama-sama (common cost) untuk melaksanakan seluruh program atau kegiatan unit kerja. Oleh karena itu dalam perhitungan SAB anggaran belanja tidak langsung dalam satu tahun anggaran harus dialokasikan ke setiap program atau kegiatan yang dilaksanakan dalam tahun anggaran yang bersangkutan.

Walaupun belanja tidak langsung ini tidak dipengaruhi secara langsung oleh program atau kegiatan satuan kerja perangkat daerah, namun diperlukan untuk menunjang aktivitas kerja seperti adanya kegiatan belaja tidak terduga dan lain-lain untuk itu penetapan anggaran belanja tidak langsung ini tetap harus diperhatikan dalam pengelolaannya dan penetapan anggarannya pun dikelola dengan baik sesuai kebutuhan.

5. Realisasi anggaran berpengaruh signifikan terhadap kinerja instansi pada Dinas Penanaman Modal dan Pelayanan Terpadu Satu Pintu Kabupaten Balangan Kalimantan Selatan.

Hasil penelitian diketahui bahwa realisasi anggaran berpengaruh signifikan terhadap kinerja instansi pada Dinas Penanaman Modal dan Pelayanan Terpadu Satu Pintu Kabupaten Balangan Kalimantan Selatan. penelitian ini sejalan dengan penelitian yang dilakukan oleh Meviana Susilowati yang menyatakan bahwa realisasi anggaran berpengaruh signifkan terhadap kinerja instansi. ${ }^{10}$ Anggaran publik berisi rencana kegiatan yang dipresentasikan dalam bentuk rencana perolehan pendapatan dan belanja dalam satuan moneter. Dalam bentuk yang paling sederhana anggaran publik merupakan suatu dokumen yang menggambarkan kondisi keuangan dari suatu organisasi yang meliputi informasi mengenai pendapatan, belanja, dan aktivitas. Sebagaimana pendapat menurut Hakim yaitu penetapan anggaran berfungsi sebagai pedoman pemerintah daerah dalam mengelola keuangan daerah untuk satu periode dimasa yang akan datang. ${ }^{11}$ Sebagai alat ukur untuk meningkatkan pelayanan publik dan kesejahteraan masyarakat daerah. Sebagai alat pengawasan bagi masyarakat daerah terhadap kebijakan-kebijakan yang

9 Titin Vegirawati, "Pengaruh Alokasi Belanja Langsung Terhadap Kualitas Pembangunan Manusia (Studi Kasus Pada Pemerintah Kabupaten Kota Di Sumatera Selatan)," Jurnal Ekonomi Dan Informasi 2, no. 1 (2012): 80.

${ }^{10}$ Susilowati, Analisis Pengaruh Belanja Daerah Terhadap Capaian realisasi anggaran dan Kinerja Instansi Pemerintah (Studi Kasus Pada SKPD Di Boyolali.

${ }^{11}$ Abdul Hakim, Dasar-Dasar Keuangan Dan Pembelajaan Perusahaan (Yogyakarta: Cahaya Atma Pustaka, 2010), 13.

Al Qalam: Jurnal Ilmiah Keagamaan dan Kemasyarakatan Vol. 16, No. 2

Maret - April 2022 
Rediyono, Ana Rahmiaty, Didik Cahyono : Pengaruh Belanja Langsung dan Belanka Tidak Langsung Terhadap Realisasi Anggaran dan Kinerja Instansi Pada Dinas Penanaman Modal dan Pelayanan Terpadu Satu Pintu Kabupaten Balangan Kalimantan Selatan

diambil oleh pemerintah daerah. Sebagai alat mengevaluasian kinerja pemerintah daerah dalam periode tertentu.

Sejalan dengan hasil penelitian tersebut, hendaknya Dinas Penanaman Modal dan Pelayanan Terpadu Satu Pintu Kabupaten Balangan Kalimantan Selatan, harus dapat mengelola anggaran keuangan baik pendapatan maupun belanja, agar aktivitas organisasi dalam memberikan pelayanan terkait dalam aktivitas penanamanmodal maupun aktivitas pelayana periiznan dapat selalu ditingkatkan sesuai dengan meningkatnya anggaran yang ditetapkan, hendaknya serapan anggaran dapat di serap sesuai kebutuhan yang dapat membentu meningkatkan kinerja instansi.

\section{KESIMPULAN}

1. Hasil penelitian pertama diketahui bahwa belanja langsung berpengaruh signifikan terhadap realisasi anggaran pada Dinas Penanaman Modal dan Pelayanan Terpadu Satu Pintu Kabupaten Balangan Kalimantan Selatan.

2. Hasil penelitian kedua diketahui bahwa belanja tidak langsung berpengaruh signifikan terhadap realisasi anggaran pada Dinas Penanaman Modal dan Pelayanan Terpadu Satu Pintu Kabupaten Balangan Kalimantan Selatan

3. Hasil penelitian ketiga diketahui bahwa belanja langsung berpengaruh signifikan terhadap kinerja instansi pada Dinas Penanaman Modal dan Pelayanan Terpadu Satu Pintu Kabupaten Balangan Kalimantan Selatan,

4. Hasil penelitian keempat diketahui bahwa belanja tidak langsung berpengaruh signifikan terhadap kinerja instansi pada Dinas Penanaman Modal dan Pelayanan Terpadu Satu Pintu Kabupaten Balangan Kalimantan Selatan

5. Hasil penelitian kelima diketahui bahwa realisasi anggaran berpengaruh signifikan terhadap kinerja instansi pada Dinas Penanaman Modal dan Pelayanan Terpadu Satu Pintu Kabupaten Balangan Kalimantan Selatan.

\section{DAFTAR PUSTAKA}

Fadli, Hendra. Anggaran Berbasis Kinerja Penyusunan APBD Secara Komprehensif. Yogyakarta: UPP STIM YKPN, 2013.

Hakim, Abdul. Dasar-Dasar Keuangan Dan Pembelajaan Perusahaan. Yogyakarta: Cahaya Atma Pustaka, 2010.

Mahsun. Manajemen Keuangan Publik. Jakarta: PT. Rajawali Press, 2006.

Nugroho, dan Rohman. Ekonomi Pembangunan. Jakarta: Liberty, 2012.

Al Qalam: Jurnal Ilmiah Keagamaan dan Kemasyarakatan Vol. 16, No. 2

Maret - April 2022 
Rediyono, Ana Rahmiaty, Didik Cahyono : Pengaruh Belanja Langsung dan Belanka Tidak Langsung Terhadap Realisasi Anggaran dan Kinerja Instansi Pada Dinas Penanaman Modal dan Pelayanan Terpadu Satu Pintu Kabupaten Balangan Kalimantan Selatan

Salam, Rudie Noor. 2019. Pengaruh Belanja Langsung Dan Belanja Tidak Langsung Terhadap Kinerja Instansi Pada Dinas Pendidikan Kabupaten Balangan. STIE Pancasetia Banjarmasin. Banjarmasin.

Susilowati, Meviana. 2012. Analisis Pengaruh Belanja Daerah Terhadap Capaian realisasi anggaran dan Kinerja Instansi Pemerintah (Studi Kasus Pada SKPD Di Boyolali. Fakultas Ekonomi Universitas Muhammadiyah Surakarta. Surakarta.

Vegirawati, Titin. "Pengaruh Alokasi Belanja Langsung Terhadap Kualitas Pembangunan Manusia (Studi Kasus Pada Pemerintah Kabupaten Kota Di Sumatera Selatan)." Jurnal Ekonomi Dan Informasi 2, no. 1 (2012).

Widodo, Arya. Penganggaran. Bandung: Buana Press, 2011.

Al Qalam: Jurnal Ilmiah Keagamaan dan Kemasyarakatan Vol. 16, No. 2

Maret - April 2022 